University of Wollongong

Research Online

Faculty of Science, Medicine and Health -

Papers: part A

Faculty of Science, Medicine and Health

$1-1-2017$

\title{
Pleistocene shell tools from Lake Mungo lunette, Australia: identification and interpretation drawing on experimental archaeology
}

\author{
Erica Weston \\ La Trobe University \\ Katherine A. Szabo \\ University of Wollongong, kat@uow.edu.au \\ Nicola Stern \\ La Trobe University
}

Follow this and additional works at: https://ro.uow.edu.au/smhpapers

Part of the Medicine and Health Sciences Commons, and the Social and Behavioral Sciences

Commons

\section{Recommended Citation}

Weston, Erica; Szabo, Katherine A.; and Stern, Nicola, "Pleistocene shell tools from Lake Mungo lunette, Australia: identification and interpretation drawing on experimental archaeology" (2017). Faculty of Science, Medicine and Health - Papers: part A. 3583.

https://ro.uow.edu.au/smhpapers/3583

Research Online is the open access institutional repository for the University of Wollongong. For further information contact the UOW Library: research-pubs@uow.edu.au 


\title{
Pleistocene shell tools from Lake Mungo lunette, Australia: identification and interpretation drawing on experimental archaeology
}

\author{
Abstract \\ Three freshwater mussel shell tools recovered from the Lake Mungo lunette, in semi-arid south-eastern \\ Australia with bracketing age estimates of $40-30 \mathrm{ka}$, and a possible fourth tool with bracketing age \\ estimates of 50-40 ka, are described. An experimental approach, combined with detailed structural and \\ taphonomic analysis of the shell establishes the presence of both deliberate cultural modification and \\ wear traces from use on the mussel fragments. The characterization of Australian Pleistocene stone \\ artefacts as being simple and unchanging is steadily being challenged through recent studies of \\ Pleistocene assemblages from Lake Mungo and elsewhere, and these early shell tools reinforce the \\ multidimensionality of ancient Australian technologies.

\section{Disciplines} \\ Medicine and Health Sciences | Social and Behavioral Sciences

\section{Publication Details} \\ Weston, E., Szabo, K. \& Stern, N. (2017). Pleistocene shell tools from Lake Mungo lunette, Australia: \\ identification and interpretation drawing on experimental archaeology. Quaternary International, 427 \\ 229-242.
}




\title{
Pleistocene Shell tools from Lake Mungo Lunette, Australia: Identification and interpretation drawing on experimental archaeology
}

\author{
Erica Weston ${ }^{1}$, Katherine Szabó ${ }^{2}$ and Nicola Stern ${ }^{1}$ \\ ${ }^{1}$ Department of Archaeology and History, La Trobe University, Melbourne, Australia \\ ${ }^{2}$ Corresponding author. Centre for Archaeological Science, University of Wollongong, \\ Wollongong NSW 2522, Australia. kat@uow.edu.au
}

\begin{abstract}
Three freshwater mussel shell tools recovered from the Lake Mungo lunette, in semi-arid south-eastern Australia with bracketing age estimates of 40-30 ka, and a possible fourth tool with bracketing age estimates of 50-40 ka, are described. An experimental approach, combined with detailed structural and taphonomic analysis of the shell establishes the presence of both deliberate cultural modification and wear traces from use on the mussel fragments. The characterization of Australian Pleistocene stone artefacts as being simple and unchanging is steadily being challenged through recent studies of Pleistocene assemblages from Lake Mungo and elsewhere, and these early shell tools reinforce the multidimensionality of ancient Australian technologies.
\end{abstract}

\section{Keywords}

Shell tool, Experimental archaeology, Lake Mungo, Pleistocene archaeology, Australian prehistory

\section{1: Introduction}

Expedient shell tools are being identified more frequently in archaeological assemblages as awareness of these types of tools, and the techniques for identifying and analysing them, improves (e.g. Lucero, 2004, Szabó, 2005, Lammers, 2008, Harris, 2011, Romagnoli et al., 2014, Fujita and Melgar, 2014, Cuenca-Solana, 2015, Szabó and Koppel, 2015). Despite this recent work, there remain considerable gaps in our knowledge of the criteria that can be used to identify and interpret shells across a wide range of taxa that have been modified for and through use. Here, we present the identification of utilised freshwater mussel shells from the Pleistocene landscape at Lake Mungo, coupled with innovative techniques for their recognition and interpretation.

An understanding of the structural composition and internal arrangement of the specific shell taxa being studied underpins all robust analytical methodologies when examining worked shell. Such considerations are presented here, followed by an experimental use- 
wear programme prefacing the analysis of archaeological freshwater mussels collected during recent foot surveys at the Mungo lunette in south-eastern Australia.

The archaeological traces preserved in the Mungo lunette span the known history of human settlement in Australia (Bowler et al., 2003, Stern, 2014) and are contained in sediments that record prevailing environmental conditions. They thus present an unparalleled opportunity to investigate the changing pattern of life on the edge of Australia's arid core and the shifts in diet and foraging strategies, technology and social networks that were developed in response to environmental changes. To achieve this goal, past activity traces, their content and sedimentary and stratigraphic context, are being systematically documented (Stern et al., 2013, Fitzsimmons et al., 2014).

The identification of utilised mussel shells amongst these activity traces provides insights into an aspect of Pleistocene Australian technologies long-recognized as being underrepresented in archaeological record, especially compared to the abundance and variety of organic tools recorded in ethno-historic documents and housed in museum collections (Mulvaney, 1961). Here we discuss some of the implications of this finding for the Willandra, as well as the Australian archaeological record more broadly.

\section{2: Background}

\subsection{Molluscs in the archaeological and palaeontological record at the Willandra Lakes}

Lake Mungo is one of a series of now-dry lakes that formed part of an ancient overflow system that lies in the semi-arid, south east of the Australian continent (Figure 1). The Willandra Lakes were inscribed on the World Heritage register in 1981 on the basis of both cultural and natural heritage values, in particular, the record they preserve of the impact of global climate change on a low-latitude, semi-arid landscape and the witness they bear to the world of the First Australians (Mulvaney and Bowler, 1981). This includes evidence for the world's oldest-known ritual human burials and some of the oldest archaeological traces on the Australian continent (Stern, 2014); at the time the original discoveries were made, it also included what was then the oldest-known evidence for the exploitation of inland aquatic resources (Barbetti and Allen, 1972). Unfortunately, a paucity of systematic archaeological research over the past 40 years means that current knowledge of the economic, technological and social strategies that sustained people's lives in this area during the long history of human settlement remains limited.

Bowler's pioneering geomorphological research established a link between the characteristics of the sediments that built up on the eastern margins of these lakes and the prevailing hydrologic conditions. Alternating cycles of lake filling, fluctuating and drying were driven by changes in a distant catchment in the south-east Australian highlands that 
have been linked to regional and global shifts in climate (Barrows et al., 2001, 2004, Bowler, 1971, 1998, Bowler et al., 2012, Fitzsimmons et al., 2014, Kemp and Rhodes, 2010). Alternating layers of sand, pelletal clay and soil in the lunette sequences record these changing lake conditions (Bowler, 1998, Bowler et al., 2012).

Based on detailed studies of the southern end of the Mungo lunette, Bowler divided the lunette sequence at Lake Mungo into a series of stratigraphic units, the base of each defined by a lake transgression and the top, by a soil representing a depositional hiatus (Bowler, 1998, Bowler et al., 2012). Recent work in the central Mungo lunette has identified a similar, though not identical sequence, reflecting some lateral variation in the net accumulation of sediment along the length of the lunette (Fitzsimmons et al., 2014). The greatest volume of sediment in the central part of the lunette is made up of Unit $E$ (the lateral equivalent of Bowler's Arumpo and Zanci units), deposited in the lead up to, during and immediately following, the Last Glacial Maximum. Exposures of the older lunette strata (Bowler's Lower and Upper Mungo units) are relatively thin and laterally discontinuous in this area (Fitzsimmons et al., 2014).

The most abundant evidence for the exploitation of lake resources in the central Mungo lunette comes from Unit E which was deposited between 24 and $14.5 \mathrm{ka}$ (Fitzsimmons et al., 2014, Fitzsimmons, et al. 2015). Hearths that contain nothing but the remains of burned and unburned fish bone are found only in this unit (Stern, 2014) and radiocarbon age determinations indicate that they all accumulated at the height of the Last Glacial Maximum (Long et al., 2014). These LGM fish bone hearths contain the remains of small numbers (925) of a single species of fish, the Golden Perch (Macquaria ambigua (J. Richardson, 1845)). Oxygen isotope and trace element analyses of a sample of Golden Perch otoliths show that the fish entered a freshwater lake several years before their death and that salinity levels increased during their sojourn in the lake (Long et al., 2014). Although it has been suggested that the death of these fish in relatively more saline waters supports Bowler's suggestion (1998) that stupefied fish were scooped up from shallow waters (Long et al., 2014), the size and numbers of fish is consistent with more than one capture technique (Lovell, 2015).

Fish bones and small fragments of mussel shell are found in some hearths in all the stratigraphic units. However, no shell middens were encountered in the $2-\mathrm{km}^{2}$ foot survey area in the central part of the lunette (Stern et al., 2013). Bowler et al. (2012) report one small midden further north on the lunette that dates to the Last Glacial Maximum and whilst others may emerge as a result of ongoing erosion, it is evident that shell middens are a rare feature of Mungo's archaeological record. Johnston (1993) has previously pointed out that throughout the Willandra Lakes, middens are scarce and where they do occur, are small, suggesting that shellfish did not play as great a role in the diet as often assumed. A compilation of radiocarbon age determinations for otoliths and bivalves from across the Willandra reveals two clusters, one that coincides with the onset of continental aridity ca. 
$40 \mathrm{ka}$ and one that coincides with the LGM (Bowler et al., 2012). This suggests that shellfish were a fall-back food, exploited primarily when specific environmental conditions were experienced, during restricted time intervals.

\subsection{Regional ethnographic evidence for freshwater mussel tool use}

The possibility that the shells of freshwater mussels might have been used as tools in inland Australia has not been widely canvassed. Clark (1987, p. 51) reports the discovery of a worked Alathyria jacksoni valve near a midden of Velesunio ambiguus shells; it was found by Mike Mclntyre during survey work at the Willandra Lakes in the 1970s (McIntyre, pers. comm. 2012). The only other evidence for the use of freshwater mussels for tools derives from the ethnographic literature. Given that the Willandra Lakes have been dry since at least $14.5 \mathrm{ka}$, it is not surprising that no such evidence has been reported for this region. However, there are ethno-historic records indicating the use of freshwater mussels as tools in the wider Murray-Darling basin.

The ethno-historic literature records two major uses of mussel shells as tools in the MurrayDarling area, hide processing and string/twine production. In both instances the shells are used as scrapers. The use of freshwater mussel shells as scrapers for possum hides in particular is reported for the 'Yarra Tribe' of Victoria (Smyth, 1878, pp. 270-271) and along the Murray and Loddon Rivers in the 1840 (Beveridge, 2008, pp.156-157)(see also Lawrence, 1968). In all accounts, possum skins are stretched out to dry and then any remaining fat is scraped away with a freshwater mussel shell. In the Hunter District of New South Wales, chips of shell are recorded as having been used for 'skinning' (Fawcett, 1878 in McCarthy and Davidson, 1943). Allen (1972, Plate 3.1) reproduces a watercolour by Gerard Krefft showing a woman on the Murray River, which he visited in 1856-7, scaling a fish with a freshwater mussel valve.

The processing of what is commonly known as bulrush, cattail or Cumbungi (Typha orientalis) using freshwater mussel valves has also been reported in various ethnographic sources. Allen (2010) describes how the root fibres were cooked and chewed producing a fibre that was formed into lengths using mussel shell scrapers (see also Coutts, 1977). This string was used to produce nets for fishing which sometimes reached $100 \mathrm{~m}$ in length (Allen, 2010). A similar process is described by Paakantyi (Barkindji) Elders for producing string from Typha dominengsis (Gott and Hercus, 2007:35). Tanya Charles, a Muthi Muthi woman and Mungo National Park Discovery Ranger, observed that in addition to scraping hides and processing plant material, mussel shell tools were used traditionally to scrape wood and bark and to process animal meat (pers. comm. August 2012).

These ethnographic records demonstrate that freshwater mussel shells were used by diverse Indigenous groups across the Murray-Darling Basin and beyond to perform a range 
of tasks, but particularly those involving a cutting or scraping action. This information, coupled with the recovery of a series of seemingly worked and/or utilised valves collected during 2009-2012 foot surveys, prompted the formulation of a research design to investigate whether archaeological mussel shell tools were present. This research design incorporated detailed investigations of the structure, microstructure and taphonomic proclivities of the relevant freshwater mussel species, an experimental use-wear program, and visual assessment of the archaeological specimens using low-power, reflected light microscopy.

\section{Methods and materials}

Usewear studies of putative shell tools have been more of a novelty than a mainstay in the archaeological literature until recently. Following from this, methods were frequently under-developed and intuitive, and few older studies took account of the vastly different structures and properties of different types of shell (e.g. Cleghorn, 1977, Pryzwolnik, 2003, Toth and Woods, 1989). Neither have most studies taken account of the divergence of shell as a raw material - in its array of structural forms - compared to the rocks and minerals used to make stone tools, from which analytical methods and interpretations are commonly drawn (e.g. Barton and White, 1993, Cleghorn, 1977). Indeed some studies do not identify the molluscan raw material at all (e.g., Choi and Driwantoro, 2007) presenting clear obstacles to a refined and tailored analytical methodology. Given the common lack of underpinning regarding raw material structure and the impact of taphonomic processes, recent studies which rely on high-power (scanning electron microscopy) methods without initial low-power analysis and detailed taphonomic assessment must be viewed with some scepticism (e.g. Velázquez Castro et al., 2011, Melgar Tisoc, 2011, see also Mannino, 2012 for discussion).

Our methodology here does not seek to over-reach, but to work towards building up the foundations of shell tool analytical methodologies. We do not aim to correlate specific ethnographically-documented activities with use-wear traces but rather focus on the interaction of mussel edges with different material textures of local relevance. Comparison with freshwater mussel specimens altered by a known set of taphonomic processes allows us to (1) identify culturally-mediated modification of mussel valves as distinct from those altered by natural processes, and, where relevant (2) document the variety of use-wear signatures present on mussel edges and suggest the types and textures of materials which may have generated such modifications.

\subsection{Freshwater mussel raw materials}

Three species of freshwater mussel within the Hyriidae are commonly found in the MurrayDarling Basin in the vicinity of the Willandra Lakes: Alathyria jacksoni Iredale, 1934, A. condola Iredale, 1943 and Velesunio ambiguus (Philippi, 1847) (Figure 2). All three species 
inhabit the bottom of streams, rivers and lakes and, as with other members of superfamily Unionacea, require the presence of fish to host the parasitic larval stage of the breeding cycle (Walker, 1981). Although morphological characteristics are traditionally used to separate the three species, it has been demonstrated that these species are highly morphologically plastic, with differences in shape revealing more about habitat and environmental conditions than taxonomy (Sheldon and Walker, 1989, Fawcett, 2009). This point has been further reinforced by the study of mitochondrial and nuclear DNA sequences across these species which shows a poor correlation between morphological features and genetic signatures (Fawcett, 2009). For the purposes of this study, these genetic differences matter little, as the structures and morphologies of the three species largely converge. Both norms and variation in structure and morphology will thus be discussed as one, together with the influence of both environment and taphonomic processes. The shells will be referred to throughout as hyriid mussels, rather than allocating a potentially-spurious species name.

Hyriid shell is comprised of three layers: an outer prismatic layer, a middle layer of lenticular nacre and an inner layer of sheet nacre (Taylor et al., 1969, Taylor, 1973, Graf and Cummings, 2006). As outlined in other papers on shell-working (Szabó, 2008, Szabó, 2013), nacre is composed of tablets of aragonite stacked in columns which, in bivalves, coalesce into sheets. Thin layers of proteins bind both the crystal tablets and sheets (Checa and Rodriguez-Navarro, 2001). These sheets run parallel to the surface of the shell meaning that when force is applied to the shell exterior, cracks have no clear path through which to travel and often dissipate laterally (Currey, 1977). Of note is the fact that force applied between sheets, such as directed force at the ventral margin of the shell, will tend to travel quite cleanly between sheets (Currey, 1977).

\subsection{Freshwater mussel taphonomy}

Decay processes begin during the life of any mollusc, and shell must be continually maintained to ensure the animal's survival. The periostracum - or outermost organic 'skin' protects the valve from acid dissolution. In hyriids and many other freshwater bivalves, the periostracum on the oldest parts of the valves gradually wears away, exposing the prismatic layer underneath. Thus, there is frequently major deformation of the dorsal/umbo area of the valve where environmental exposure has abraded or dissolved away part of the shell surface (Roper and Hickey, 1994) and the effects of these processes can be clearly seen in Figure 2.

After the death of the animal, the shell is subject to a range of taphonomic processes which vary according to depositional context (Zuschin et al., 2003). In the case of the windswept shifting sediments of the Willandra Lakes, valves quickly fragment upon exposure (Allen, 1998, see also Balme, 1995). Before disappearance, however, evidence of a number of 
processes can be visually detected of valve surfaces. Most notably this includes attrition of edges and surfaces, as well as polish, to all exposed areas caused by sandblasting (see Figure $3)$.

After the death of the animal and exposure of the shell to the elements, the organic proteins which coat and bind the shell's crystals and layers rapidly degrade (Vermeij, 1993). The speed at which this process happens is accelerated if the shell is exposed to acid through vectors such as rainwater or decaying plant matter (Kotzian and Simoes, 2006). The degradation of proteins within the shell structure means that shells are more prone to fragmentation and splitting along and between layers, and this is particularly so with shells such as hyriid mussels where the primary building material is organic-rich nacre (Zuschin and Stanton, 2001). In the context of the Mungo lunette, trampling and movement of shells caused by native and introduced fauna, such as emus, kangaroos, goats and rabbits, further exacerbate problems of fragmentation and the continual exposure of previously-buried material.

In addition to fragmentation of valves, the chipping of valve margins post-mortem in fluvial contexts has been noted to be much higher than for marine bivalves (Kotzian and Simoes, 2006). Bioeroders - both microscopic and macroscopic - are also constantly acting upon shells, with their actions impacting more on the shell post-mortem when the mollusc cannot rebuild the shell (Vermeij, 1993).

All experimental specimens and archaeological samples underwent a taphonomic assessment prior to further analysis in order to locate and identify any areas of taphonomic alteration. Observations were also made of shells exposed on the present day lunette in order to identify and characterise the major taphonomic processes at play in the modern Mungo environment. High-velocity sand damage and acid dissolution from rain exposure were noted as the two most common vectors of hyriid modification at Mungo today. The specimens used for usewear experiments had been collected live or very recently dead, so wind-blown sand damage was not a factor. Taphonomic alterations were identified to varying degrees on the archaeological samples collected during foot surveys and salient details of these are presented in the results.

\subsection{Experimental use-wear}

Forty-eight hyriid bivalves from the Murray-Darling Basin in Victoria were sourced for experimental work. Following standard morphological taxonomic keys, the samples comprised examples of $V$. ambiguus, A. jacksoni and $A$. condola. Since it was unclear whether past uses of the valves would have involved modified or unmodified valves, the interior margins of half of the valves were notched (Figure 4), while the remaining half were left in their natural state. Notches were created through direct freehand percussion using a 
small cobble. This could only be done with the more robust hyriid specimens as smaller, more fragile examples repeatedly suffered catastrophic failure of the shell.

Four materials to be worked were selected based on local ethnographic accounts of the uses of hyriid mussels as tools, but also because they represented distinctly different textures for working. These included the skin of the Common Brushtail Possum (Trichosurus vulpecula (Kerr, 1792)), bulrush (Typha domingensis Pers.), Red River Gum (Eucalyptus camaldulensis Dehnh.) wood and sweet potato (Ipomoea batatas (L.) Lam.). The latter is neither a traditional food nor native to the Mungo area, but provided a textural contrast and analogue for the preparation of tubers such as the native Daisy Yam (Microseris lanceolata (Walp.)).

The possums had been skinned using a knife, stretched and pegged on a board, and left out in the open to dry for a week. Once dry, the skins were unpegged and scraped 200 times each with two notched and two un-notched valves (see Figure 5a). The bulrush leaves were freshly-collected and then dried over a low-temperature fire for 2-3 minutes. They were rotated constantly to prevent burning. They were then scraped lengthwise 200 times with two notched and two un-notched valves (Figure 5b). The bark and wood of the Red River Gum was fresh and thus relatively 'wet', and was scraped and sliced 200 times using two notched and two un-notched valves (Figure $5 \mathrm{c}$ ). Sweet potatoes were fresh and whole and were rinsed before peeling and slicing 200 times using two notched and two un-notched valves (Figure $5 \mathrm{~d}$ ).

It should be noted that although 'duration of time worked' is a common measure of the intensity of working of experimental specimens, we preferred to use the more precise measure of 'number of actions'. Although this means that our study is not directly comparable with those of others, the specific natures of raw materials being worked and the differing structures of the shells studied means that direct comparisons would already be inappropriate. Two hundred repetitive actions for each specimen was found to generate sufficient wear traces for analysis. Ideally, experiments would have been repeated using an increased number of total actions to assess the development of use traces with extended working, however the critically-endangered status of some of the hyriids used for the study meant that insufficient valves were available for this.

\subsection{Analysis of archaeological freshwater mussel shell}

Eight specimens of hyriid shells showing potential signs of working or use were located during systematic foot surveys undertaken in the central Mungo lunette in 2011 and collected in 2012. Another two hyriid fragments that had been modified through weathering and transport were also collected in 2012 to enable detailed comparisons with those 
suspected of being tools. Due to the fragility of the specimens, analytical work was undertaken at Mungo National Park so that no transport of the archaeological specimens was required.

The eroding surface of the Mungo lunette preserves residuals of intact sediment that stand above the surrounding slope-wash surfaces or rill and gully systems. Three of the shell tools described in this paper were found at the base of a residual following a series of heavy rainfall events in the summer of 2011; the fourth was found on a gentle slope $\left(<6^{\circ}\right)$ immediately below a low ridge. All but one of the tools and other shell fragments were found in areas that had been inspected systematically for finds during foot survey work in 2009 and 2010. During the survey a line of searchers walked 1.5 metres apart across $50 \mathrm{~m} \mathrm{x}$ $50 \mathrm{~m}$ grid squares, twice (in different direction and light conditions). Nearly all of the shells were found when these grid squares were re-walked in 2011 as part of a strategy to assess the impact of high magnitude rain events on the preservation of cultural features. Only one exhibited obvious macroscopic evidence for post-exposure abrasion when observed in the field. It lay trapped amongst a scatter of carbonate nodules on an extensive, stable platform of Golgol lag and was recorded during the original foot survey of this area in 2009.

All archaeological shell specimens are held by the Indigenous Traditional Owners in safekeeping at Mungo National Park. As the shells could not be removed from their repository, all analysis was done at the Leaghur Shearers' Quarters within the Park. This meant that a portable analytical set-up had to be used. All fragments were visually assessed using a Dinolite Premier AM4012MZT portable digital microscope, with all areas of clearly taphonomic and non-taphonomic modifications being photographed and recorded. The experimental specimens were also on hand during this analysis so that comparisons of modifications could be made during analysis.

\section{Results}

The results of the experimental usewear program, as well as the analysis of taphonomicallyaltered samples, form the basis for the interpretation of the archaeological specimens. The experimental samples, including details of specific modifications and their placement on the valve, will be presented first, followed by the results of analysis of the archaeological hyriids collected during foot surveys.

\subsection{Results of experimental usewear studies}

Hyriid valves used for scraping possum skins showed a series of distinctive modifications. A strong line of polish developed along the ventral margin of all specimens, with the fatty residue from the possum skin also imparting a 'greasy' appearance (Figure 6a). Some microchipping was observable on the edges of the larger shells, while larger chips detached 
from the margin of smaller shells. Where edges were preserved, about $50 \%$ of contact edges showed observable traces of edge-rounding. Discoloration from two separate processes was also noted along the working edges. A grey residue staining across and back from the working edge on the interior valve surface was clearly present on three of the four experimental specimens. Across all specimens there was also a translucent zone right at the working edge which was the result of the pressure applied to the shell margin during working forcing different layers of nacre apart, which alters the refractive properties of the nacre.

The hyriid valves used for scraping bulrush also showed a cohesive suite of modifications. The ventral margins showed edge-rounding and a patchy line of polish. In the notched tools, the interior of the notches did not show polish or rounding, but these zones did accumulate plant fibres and cellulose residue. Additionally, residue build up in a distinct band back from the working edge and also exhibited directionality in line with the scraping action (Figure $6 b)$. There was a low incidence of edge attrition in the form of chipping or microchipping.

Hyriid valves used for scraping the more resilient plant material Red River Gum showed more pronounced usewear modifications. These included edge-rounding, the build-up of residues in the notches of notched specimens and in a band back from the working edge, and microchipping visible from both the interior and exterior surfaces of the valve (Figure $7 \mathrm{a}$ and 7b). Most utilised edges developed discernible striations in line with the direction of use.

Lastly, the hyriid valves used in the scraping and slicing of sweet potato showed heavy edge attrition in the form of both rounding and the separation and exfoliation of nacre sheets at the margin (Figure 8). The majority of the wear traces manifest on the interior margin of thee valve. The soft, moist nature of the sweet potato meant that residue readily dispersed along and back from the working edge, with pieces becoming lodged in notches and between separated lamellae. It is probably this latter tendency which resulted in the differential exfoliation of different shell layers with continued use.

The experimental use-wear program revealed a consistent set of modifications across all activities, including edge-rounding, micro-chipping and exfoliation of the shell layers at the working edge and residue accumulation in a band back from the working edge. The only distinctive use-wear trace was the development of directional striations with wood-working. These results limit our ability to tie any archaeological use-wear traces - even in the broadest terms - back to the working of particular classes of material. However, all of these traces diverge from those noted as taphonomic alterations in unworked valves and valve fragments, including widespread polish and attrition due to the action of wind-blown sand, the separation of nacre layers across large patches of surface area and acid dissolution pitting due to exposure to surface water. Additionally, the experimental valves always 
showed highly concentrated patches of use-wear which tied precisely to the working edge of the tool, while other valve surfaces remained in their natural state. Thus, the analysis of the archaeological specimens was guided not only by the types of modifications that were observed, but also their extent.

\subsection{Results of analysis of archaeological hyriids}

Of the eight hyriid ventral margin fragments identified as possible tools during foot surveys at Mungo, three were identified as tools with a further example placed in an equivocal category. The remaining four showed signs of taphonomic, but not cultural, modification.

\#1110 - identified as a tool

This specimen is a long fragment of ventral margin with invasive notches along the ventral margin. The surface shows minor acid dissolution pitting - probably from exposure to surface water. Edge rounding and polish are observable on a plane along either side of notch on the ventral margin with rounding and polish also noted in the notch. Other sections of the break surface are thin and crisp. The use-wear is thus highly-focussed along one area of the margin (Figure 9).

\#1108 - identified as a tool

This artefact is a fragment of ventral margin with shallow notches along the ventral margin and break surface parallel to the margin (Figure 10). The morphology of these notches suggests that they are likely taphonomic. Edge-rounding and polish is observable along the ventral margin but not within the notches, which further suggests that the notches were present in the original raw material. There is differential wear along the utilised edge, with the innermost layers showing the greatest levels of removal resulting in a facet-like appearance. The outer surface of the fragment shows some acid dissolution and polish caused by wind-borne sand.

\#1104 - identified as a tool

This artefact is a fragment of ventral margin with invasive notches along the break surface parallel to the margin (Figure 11). The notches are deep and clearly worked from exterior surface of valve. Usewear is evident along the notched break surface rather than ventral margin in this example. Attrition and removal of outermost layers at the working edge is set in a distinct plane back from the notches. Surface staining surrounds this zone and is also observable within the notches. The interior surface of the break margin also shows rounding, staining and zones of polish.

$\# 1086$ - equivocal tool

This piece is a triangular fragment of body and ventral margin. There is muted rounding, polish and abrasion, but traces are too indistinct to differentiate from low-level taphonomic 
alteration from weathering and exposure (Figure 12). The indistinctness of the traces makes further interpretation little more than speculative.

\#1107 - unworked fragment

This specimen is a ventral margin fragment with microchipping along edges. There is no notching, but rather a natural snap fracture, along the break surface (Figure 13a, b). There is some separation of lamellae, but unlike in worked and experimental specimens were this is restricted to the zone of working, this is widespread delamination. Such large-scale delamination was noted in taphonomically-altered specimens and so this has been interpreted as such.

\#1085 - unworked fragment

This is a ventral margin fragment with micro-chipping and lamellar separation across the surface. The fragment has dull surfaces with minor acid dissolution characteristic of shortterm exposure and weathering.

\#875 - unworked fragment

This is a ventral margin fragment showing a high level of abrasion through wind-blown sand action as well as the rounding of surfaces and exposed lamellae across the surface of the fragment (Figure 13c). All modifications are characteristic of post-exposure weathering. These observations are consistent with the topographic context of this tool: it lay trapped amongst a scatter of carbonate nodules on the surface of a large, flat exposure and had probably been exposed on the modern surface for some time.

\#1064 - unworked fragment

This is a ventral margin fragment showing both weathered and more recent breaks (Figure 13d). It illustrates the process of disintegration following exposure, as lamellae become abraded and then splinter apart.

\section{Discussion}

Three definite and one possible hyriid shell tool from Pleistocene deposits at Lake Mungo were identified through this study. The use of freshwater mussel shells as tools has been recorded in the ethnohistorical literature pertaining to the broader region, but not the Willandra Lakes themselves, as they have been dry for the past 15,000 years. All the shells were located during a systematic foot survey of the central Mungo lunette, and all but one was found when previously walked grid squares were re-examined following a heavy rainfall event in 2011. Only one of the shells examined as part of this study (\#875) was exposed on the surface of the lunette when these grid squares were surveyed initially in 2009-10. 
Although the shell tools were found on the surface of the lunette, their position with respect to stratigraphic boundaries, palaeo-topographic and modern topographic features permits identification of the stratigraphic unit from which they were derived. None of the tools was recovered from a setting in which sediments from an older or younger stratigraphic unit lie upslope. None of them could have been transported to their findlocation by water flowing across a slope wash surface or down a rill or gully.

Tool \#1104 lay on red sands at the base of a small residual made up entirely of Unit C (Upper Mungo) sediments. No rills or gullies lead into this surface and there are no exposures of other stratigraphic units at higher elevation that could have contributed material to this surface as they eroded away. Although its precise stratigraphic origin cannot be determined, it is clearly derived from the Unit C (Upper Mungo) sediments in the adjacent residual. A single OSL age of 34 ka has been obtained for this unit in the central Mungo lunette (Fitzsimmons et al. 2014), although age determinations from other parts of the lunette suggest a time span of approximately 40- 30 ka (Bowler 1998).

Tool \#1008 lay on a gentle slope near the base of large residual of Upper Mungo sediments, near the boundary between Units C (Upper Mungo) and B (Lower Mungo). The only upslope sediments whose erosion could have contributed debris to this surface are Upper Mungo sediments, as the only rills cutting back into these sediments originate at the base of the residual of Upper Mungo sediments.

Tool \#1110 lay on gently sloping apron of Unit C (or Upper Mungo) sediments, immediately below a small residual also comprising Unit $C$ sediments. It was not lying on this surface when the area was surveyed during the 2009 foot survey or when OSL samples were collected from the opposite side of this residual in January 2010.

Tool \#1086 lay on a $6-12^{\circ}$ slope made up of Unit B (Lower Mungo) sands, below the crest of a low ridge also comprising Unit B sands. As the immediate upslope catchment is made up solely of Lower Mungo sands, this is the inferred stratigraphic origin of this tool. Dates for this unit from both the southern and central portion of the lunette suggest that it accumulated from approximately 55- 40 ka (Bowler, 1998, Fitzsimmons et al., 2014).

A clear difference between the mussel-shell tools described in the ethnohistoric accounts and those recovered from Pleistocene deposits is the presence of deliberate notching on the archaeological specimens. Regularly-spaced and deeply-invasive notching is not a characteristic of taphonomically-altered shell. Rather, the edge-chipping reported for fluvially-transported freshwater mussel valves is less invasive and more irregular in its patterning along the ventral margin (Kotzian and Simoes, 2006). These conclusions for American freshwater mussels were supported by our own observations of taphonomicallyaltered shell at Mungo. Exactly what functional benefits notching may offer are unclear, and 
there were no clear differences in efficacy between the experimental notched and unnotched valves used in this study. Regardless of intent, invasive notching itself may be a good marker of cultural modification when identifying archaeological shell tools. However, we feel coupling observations of notching with usewear serves to make interpretations much more robust.

The identification of utilised shell tools from Pleistocene contexts at Lake Mungo adds to the suite of stone artefacts reported previously (e.g. Allen, 1972, Bowler et al., 1970, Shawcross, 1998, Hiscock and Allen, 2000). The first formal description of Pleistocene Australian stone tools was based on an assemblage of artefacts eroding out from the same horizon as Mungo Lady, at the southern tip of the Mungo lunette. The definition of the 'core tool and scraper tradition' was intended to provide a framework for describing regional and temporal variation in the characteristics of Pleistocene artefact assemblages (Bowler et al., 1970), but the absence of a well-defined and widely accepted typology made it difficult to realize that goal (Holdaway and Stern, 2004, pp. 300-5). The apparent lack of change and variation in Pleistocene assemblages, together with characterization of the technology that produced them as involving simple chains of flake removals, contributes to a widely held perception that complex technologies only appeared in Australia during the Holocene, their appearance driven by population growth (Brumm and Moore, 2005, O'Connell and Allen, 2007, Moore, 2013).

Since the 1980s, technological analyses of artefact assemblages, designed to generate information about the way the tools were made, reformed and repaired, have set a new agenda for the study of stone artefacts (Hiscock, 1998), but the mis-match between typological and technological categories makes it difficult to re-interpret older data using current approaches (Hiscock and Allen, 2000). Technological analyses are being combined with interpretive approaches that draw on the fundamental principles of evolutionary ecology to provide insights into the circumstances in which different strategies were employed to acquire raw material, fashion it into tools and to repair or replace those tools (e.g. Clarkson, 2007, Holdaway and Douglass, 2012). The application of these approaches to stone artefacts from Lake Mungo has demonstrated that significant shifts in technological strategies can be represented by quite subtle changes in assemblage characteristics (Tumney, 2011, Stern et al., 2013, Spry, 2014). These studies provide a framework that can usefully be applied to organic tools.

The small suite of shell tools identified here are more than freshwater valves utilised as expedient tools and certainly represent a more complex category of artefact than unmodified, repurposed midden shell (e.g. Szabó and Koppel, 2015). The combined observations of deliberate notching and the utilisation of break (rather than ventral margin) surfaces in the most heavily-worked example clearly point to the deliberate modification of hyriid valves for use as tools. Whether they were originally collected as a food source is 
impossible to know, but the lack of obvious indicators such as extensive bioerosion on the interior shell surfaces mean this is a possibility. However, regardless of original intent at the time of the shells' collection, the three (and possibly four) artefacts identified here were [re]fashioned and utilised in a patterned way with clear intent. In this, they only diverge from the broader stone artefact assemblage with respect to the raw material. Certainly, these shell artefacts should be considered as a part of the Mungo technological repertoire and complement burgeoning understanding of change and innovation in Pleistocene technologies (Tumney, 2011, Spry, 2014).

\section{Conclusions}

This paper has sought to demonstrate that the identification of usewear in shell must be linked to clear understandings of the structure and taphonomic proclivities of the specific taxa being investigated. While some usewear modifications, such as edge-rounding, polish and micro-chipping coincide with alterations often noted for stone artefacts, other features such as lamellar splitting and exfoliation are linked to the anisotropic, multi-layered nature of nacreous shell. Likewise, with regards to taphonomic processes, shell is especially susceptible to water-mediated acid dissolution and large-scale structural delamination is a particular feature of nacreous shell in the weathering process.

Little in the way of detailed criteria and methodological guides exist for the identification of worked shell, and this is particularly so for minimally-modified tools. Given this, there is a valid question around whether the rare reports of Palaeolithic shell tools (e.g. Szabó et al., 2007, Douka and Spinapolice, 2012, Romagnoli et al., 2014, Joordens et al., 2015, Szabó and Koppel 2015) are an accurate representation of frequency in the archaeological record, or whether many more remain unidentified in bags of shell midden. Certainly some recently reported finds stem from the reanalysis of shell material from older excavations (Szabó et al., 2007, Joordens et al., 2015, Szabó and Koppel, 2015).

Most importantly, the findings of Pleistocene worked shell tools at Mungo has added a new dimension to the on-going revision of Pleistocene Australian tool kit as being simple and unchanging. Stone artefact assemblages at Lake Mungo and beyond are now recognised as more diverse and complicated than suggested by earlier analytical and interpretive approaches, and the addition of a separate category of material in the form of shell tools, reinforces this multi-dimensionality. With a greater awareness of the potential presence of shell tools, and closer scrutiny of shells recovered from archaeological sites, more artefacts of this type may well be identified and serve to provide a more balanced and nuanced picture of ancient technologies.

\section{Acknowledgements}


This research was undertaken with permission from the Elders' Council of the Traditional Groups of the Willandra Lakes Region World Heritage Area and the Technical and Scientific Advisory Committee of the Willandra Lakes Region World Heritage Area. We thank the Paakantyi/Barkindji, Ngiyampaa and Mutthi Mutthi Elders for welcoming us into their country and for their involvement in this research. We are indebted to the Mungo National Park Discovery Rangers and student volunteers from La Trobe University for their contributions to the foot survey.

Possum skins were supplied by Paul Schefferle of Little River shooting range (member of the Sporting Shooters Association) and the bulrush was donated by Barwon Orange Café in Geelong, Victoria. The A. jacksoni and A. condola specimens used for experimental work were kindly donated by Dr. Peter Barker from Cohuna, northern Victoria. Figure 1 was prepared by Ming Wei, from La Trobe University. This research was funded by an Australian Research Council Linkage grant (LP0775058) and an Australian Research Council Discovery grant (DP1092966) and supported by La Trobe University and the University of Wollongong. The shells were collected under Aboriginal Heritage Impact Permit 1131516, issued to La Trobe University by the New South Wales Office of Environment and Heritage.

\section{References}

Allen, H., 1972. Where the crow flies backwards. Unpublished PhD thesis. Canberra, Australian National University.

Allen, H., 1998. Reinterpreting the 1969-1972 Willandra Lakes archaeological surveys. Archaeology in Oceania 33, 207-220.

Allen, H,. (ed.) 2010. Australia: William Blandowkski's Illustrated Encyclopaedia of Aboriginal Australia. Aboriginal Studies Press, Canberra.

Balme, J., 1995. 30,000 years of fishery in western New South Wales. Archaeology in Oceania 30, 1-21.

Barbetti, M., Allen, H., 1972. Prehistoric man at Lake Mungo, Australia, by 32,000 years BP. Nature 240, 46-48.

Barton, H., White J.P., 1990. Use of Stone and Shell Artifacts at Balof 2, New Ireland, Papua New Guinea. Asian Perspectives 32, 169-181.

Barrows, T. T., Stone, J.O, Fifield L.K., 2004. Exposure ages for Pleistocene periglacial deposits in Australia. Quaternary Science Reviews 23, 697-708. 
Barrows, T. T., Stone, J.O., Fifield, L.K., Creswell, R.G., 2001. Late Pleistocene glaciation of the Kosciuszko Massif, Snowy Mountains, Australia. Quaternary Research 55, 179-189.

Beveridge, P., 2008. On Aborigines of Victoria and Riverina. Lowden Publishing, Melbourne.

Bowler, J.M., 1971. Pleistocene salinities and climatic change: evidence from lakes and lunettes in southeastern Australia. In: D.J. Mulvaney, D.J., Golson, J., (Eds) Aboriginal Man and Environment in Australia. Australian National University, Canberra, pp. 47-65.

Bowler, J.M., 1998. Willandra Lakes revisited: environmental framework for human occupation. Archaeology in Oceania 33, 120-155.

Bowler, J.M., Gillespie, R., Johnston, H., Boljkovac, K., 2012. Wind v water: glacial maximum records from the Willandra Lakes. In: Haberle, S., David, B. (Eds.), Peopled Landscapes: Archaeological and Biogeographic Approaches to Landscapes, Terra Australis, vol. 34. Australian National University, Canberra, pp. 271-296.

Bowler, J.M., Jones, R., Allen, H., Thorne, A., 1970. Pleistocene human remains from Australia: a living site and human cremation from Lake Mungo, western New South Wales. World Archaeology 2, 39-60.

Bowler, J. M., Johnston, H., Olley, J.M., Prescott, J.R., Roberts, R.G., Shawcross, W., Spooner, N.A., 2003. New ages for human occupation and climatic change at Lake Mungo, Australia. Nature 421, 837-840.

Brumm, A., Moore, M., 2005. Symbolic revolutions and the Australian archaeological record. Cambridge Archaeological Journal 15, 157-175.

Checa, A.G., Rodriguez-Navarro, A., 2001. Geometrical and crystallographic constraints determine the self-organisation of shell microstructure in the Unionidae (Bivalvia: Mollusca). Proceedings of the Royal Society of London, Series B - Biological Sciences 268, 771-778.

Choi, K., Driwantoro, D., 2007. Shell tool use by early members of Homo erectus in Sangiran, central Java: cut mark evidence. Journal of Archaeological Science 34, 48-58.

Clark, P., 1987. Willandra Lakes World Heritage Area Archaeological Resource Study. Unpublished Report for the NSW Department of Environment and Planning.

Clarkson, C., 2007. Lithics in the Land of the Lightning Brothers: The Archaeology of Wardaman Country, Northern Territory, Terra Australis 25. ANU E Press, Canberra. 
Cleghorn, P.L., 1977. A Note on Flaked Shell Implements: An Experimental Study. Asian Perspectives 20, 241-245.

Coutts, P.J.F., 1977. Aboriginal prehistory in north-western Victoria. Ministry for Conservation, Melbourne.

Cuenca-Solana. D., 2015. The use of shells by hunter-fisher-gatherers and farmers from the early Upper Palaeolithic to the Neolithic in the European Atlantic Façade: A technological perspective. Journal of Island and Coastal Archaeology DOI:

$10.1080 / 15564894.2014 .934491$

Currey, J.D., 1977. Mechanical properties of mother of pearl in tension. Proceedings of the Royal Society, Series B - Biological Sciences 196, 442-463.

Douka, K., Spinapolice, E.E., 2012. Neanderthal Shell Tool Production: Evidence from Middle Palaeolithic Italy and Greece. Journal of World Prehistory 25, 45-79.

Fawcett, J.H., 2009. Muddy Waters: A molecular approach to clarifying freshwater mussel diversity in Australia. Unpublished PhD thesis, Griffith University.

Fitzsimmons, K. E., Stern, N., Murray-Wallace, C. V., 2014. Depositional history and archaeology of the central Lake Mungo lunette, Willandra Lakes, southeast Australia. Journal of Archaeological Science 41, 349-364.

Fitzsimmons, K.E., Stern, N., Murray-Wallace, C.V., Truscott, W., Pop, C. (2015) The Mungo mega-lake event, semi-arid Australia: non-linear descent into the last ice age, implications for human behavior. PLOS ONE 10(6), e0127008. DOI: 10.1371/journal.pone.0127008.

Fujita, H., Melgar, E., 2014. Early Holocene use of Pleistocene fossil shells for hide-working at Covacha Babisuri on Espíritu Santo Island, Baja California Sur, Mexico. Journal of Island and Coastal Archaeology 9, 111-129.

Gillespie, R., 1998. Alternative timescales: a critical review of Willandra Lakes dating. Archaeology in Oceania 33, 169-182.

Gillespie, R., Fink, D., Petchey, F., Jacobsen, G., 2009. Murray-Darling basin freshwater shells: riverine reservoir effect. Archaeology in Oceania 44, 107-111.

Gott, B., Hercus, L., 2007. A cultural biodiversity strategy with participation of Barkindji communities in natural resource management and effective land and water management 
policies. Volume 1: Main report - project method, results and recommendations. Cultural Biodiversity Strategy: Paakantyi (Barkindji) Project. Lower Murray-Darling Catchment Management Authority, Buronga.

Graf, D.L., Cummings, K.S., 2006. Palaeoheterdont diversity (Mollusca: Trigonioida + Unionoida): what we know and what we wish we knew about freshwater mussel evolution. Zoological Journal of the Linnean Society 148, 343-394.

Harris, M., 2011. Tools or tucker? Developing methods for identifying utilised Polymesoda (Geloina) erosa (Bivalvia: Corbiculidae) shell valves. Unpublished Bachelor of Social Science with Honours thesis. University of Queensland.

Holdaway, S., Douglass, M., 2012. A Twenty-First Century Archaeology of Stone Artifacts, Journal of Archaeological Method and Theory 19, pp. 101-131.

Johnston, H., 1993. Pleistocene shell middens of the Willandra Lakes. In: Smith, M.A., Spriggs, M., Fankhauser, B., (Eds) Sahul in Review: Pleistocene archaeology in Australia New Guinea and island Melanesia. Department of Prehistory, Research School of Pacific Studies, Australian National University, Canberra, pp. 197-203.

Joordens, J., d'Errico, F., Wesselingh, F.P., Munro, S., de Vos, J., Wallinga, J., Ankjærgaard, C., Reimann, T., Wijbrans, J.R., Kuiper, K.F., Mücher, H.J., Coqueugniot, H., Prié, V., Joosten, I., van Os, B., Schulp, A.S., Panuel, M., van der Haas, V., Lustenhouwer, W., Reijmer, J.J.G., Roebroeks, W., 2015. Homo erectus at Trinil on Java used shells for tool production and engraving. Nature 518, 228-231 (12 February 2015).

Kemp, J. Rhodes, E., 2010. Episodic fluvial activity of inland rivers in southeastern Australia: Palaeochannel systems and terraces of the Lachlan River. Quaternary Science Reviews 29, 732-752.

Kotzian, C., Simoes, M., 2006. Taphonomy of recent freshwater molluscan death assemblages, Touro Passo Stream, Southern Brazil. Revista Brasileira De Paleontologia 9, 243-260.

Lammers, Y., 2008. Tracing Traces from Present to Past: A functional analysis of preColumbian shell and stone artefacts from Anse a la Gourde and Morel, Guadaloupe, FWI. University of Leiden Press, Leiden.

Lawrence, R., 1968. Aboriginal Habitat and Economy. Unpublished Masters thesis. Australian National University, Canberra. 
Long, K., Stern, N., Williams, I.S., Kinsley, L., Wood, R., Sporic, K., Smith, T., Fallon, S., Kokkonen, H., Moffat, I., Grün, R., 2014. Fish otolith geochemistry, environmental conditions and human occupation at Lake Mungo, Australia. Quaternary Science Reviews 88, 82-95.

Moore, M.W., 2013. Simple stone flaking in Australasia: Patterns and implications. Quaternary International 285, 140-149.

Lovell, C., 2015. Fish and fishing at site 1168 on the Mungo lunette. Unpublished B.A. Honours Thesis, Department of Archaeology and History, La Trobe University.

Lucero, M., 2004. Evaluación del uso de artefactos de concha en el poblamiento inicial del semiarido de Chile. Unpublished PhD thesis, University of Chile.

McCarthy, F.D., Davidson, F.A., 1943. The Elouera Industry of Singleton, Hunter River, New South Wales. Records of the Australian Museum, 21, Sydney.

Mannino, M., 2012. Review of C. Çarkirlar (Ed.) Archaeomalacology Revisited: Non-dietary uses of molluscs in archaeological settings. Cambridge Archaeological Journal 22, 229-300.

Melgar Tisoc, E.R., 2011. Technological Change in Shell Object Manufacture on the Western Coastline of Chetumal Bay (Mexico). In Çarkirlar, C., (ed.) Archaeomalacology Revisited: Non-dietary uses of molluscs in archaeological settings. Oxbow, Oxford, pp. 44-53.

Mulvaney, D.J., Bowler, J.M., 1981. Lake Mungo and the Willandra Lakes. In: The Heritage of Australia: the Illustrated Register of the National Estate. Macmillan, Sydney.

O'Connell, J. F., Allen, J., 2007. Pre-LGM Sahul (Pleistocene Australia-New Guinea) and the archaeology of early modern humans. In P. Mellars, P., Boyle, K., Bar-Yosef, O., Stringer, C., (eds), Rethinking the Human Revolution: New Behavioural and Biological Perspectives on the Origins and Dispersal of Modern Humans. pp. 395-410. Cambridge: McDonald Institute for Archaeological Research, pp. 395-410.

Pryzwolnik, K., 2003. Shell artefacts from northern Cape Range Peninsula, northwest Western Australia. Australian Archaeology 56, 12-21.

Romagnoli, F., Martini, F., Sarti, L., 2014. Neanderthal use of Callista chione shells as raw material for retouched tools in south-east Italy: Analysis of Grotta del Caveallo Layer L assemblage with a new methodology. Journal of Archaeological Method and Theory DOI 10.1007/s10816-014-9215-x 
Roper, D.S., Hickey, C.W., 1994. Population structure, shell morphology, age and condition of the freshwater mussel Hyridella menziesi (Unionacea: Hyriidae) from seven lake and river sites in the Waikato River system. Hydrobiologia 284, 205-217.

Shawcross, W., 1998. Archaeological excavations at Mungo. Archaeology in Oceania 33, 183200.

Sheldon, F., Walker, K.F., 1989. Effects of Hypoxia on Oxygen Consumption by Two Species of Freshwater Mussel (Unionacea: Hyriidae) from the River Murray. Australian Journal of Marine and Freshwater Research 40, 491-499.

Smyth, R.B., 1878. The Aborigines of Victoria, volume 1. John Ferres, Melbourne.

Spry, C., 2014. Refitting a past: a comparison of late Pleistocene and Terminal Pleistocene/early Holocene stone tool technology at Lake Mungo, southwestern New South Wales, Australia. Unpublished PhD thesis, Department of Archaeology and History, La Trobe University.

Stern, N., 2014. The archaeology of Lake Mungo. In Smith, C., (Ed.), Encyclopedia of Global Archaeology. Springer, New York, pp. 4364-4375.

Stern, N., Tumney, J., Fitzsimmons, K., Kajewski, P., 2013. Strategies for investigating human responses to changes in environment at Lake Mungo in the Willandra Lakes, southeast Australia. In: Frankel, D., Webb, J., Lawrence, S., (Eds), Archaeology in Technology and Environment. Routledge, London, pp. 31-50.

Szabó, K., 2005. Technique and Practice: shell-working in the western Pacific and Island Southeast Asia. Unpublished PhD thesis, Department of Archaeology and Natural History, Australian National University.

Szabó, K., 2008. Shell as a Raw Material: Mechanical Properties and Working Techniques. Archaeofauna 17, 125-138.

Szabó, K., 2013. Identifying Worked Shell: A Consideration of Methodological Issues with particular reference to Pleistocene Contexts. In: Bailey, G., Hardy, K., Camara, A., (Eds) Shell Energy: Mollusc Shells as Coastal Resources. Oxbow Books, Oxford, pp. 277-286.

Szabó, K., Koppel, B., 2015. Limpet shells as unmodified tools in Pleistocene Southeast Asia: An experimental approach to assessing fracture and modification. Journal of Archaeological Science 54, 64-76. 
Taylor, J.D., 1973. The structural evolution of the bivalve shell. Palaeontology 16, 519-534.

Taylor, J.D., Kennedy, W.J., Hall, A., 1969. The shell structure and mineralogy of the Bivalvia. Introduction. Nuculacea - Trigonacea. Bulletin of the British Museum of Natural History (Zoology) Supplement 3, 1-125.

Toth, N., Woods, M., 1989. Molluscan Shell Knives and Experimental Cut-Marks on Bones. Journal of Field Archaeology 16, 250-255.

Tumney, J., 2011. Environment, Landscape and Stone Technology at Lake Mungo, southwest New South Wales, Australia. Unpublished PhD thesis, Department of Archaeology and History, La Trobe University.

Velázquez Castro, A., Jiménez Lara, P., Zúñiga Arellano, B., Valentin Maldonado, N., 2011. The Oliva Shell Necklace from Tlacojalpan, Vercruz, Mexico. In Çarkirlar, C. (Ed.) Archaeomalacology Revisited: Non-dietary uses of molluscs in archaeological settings. Oxbow, Oxford, pp. 87-95.

Vermeij, G.J., 1993. A Natural History of Shells. Princeton University Press, New Jersey.

Walker, K.F., 1981. Ecology of freshwater mussels in the River Murray. Australian Water Resources Council Technical Paper 61.

Zuschin, M., Stachowitsch, M., Stanton Jr., R.J., 2003. Pattern and processes of shell fragmentation in modern and ancient marine environments. Earth Science Reviews 63, 3382.

Zuschin, M. Stanton Jr., R.J., 2001. Experimental Measurement of Shell Strength and its Taphonomic Interpretation. Palaios 16, 161-170. 


\section{Pleistocene Shell tools from Lake Mungo Lunette, Australia: Identification and interpretation drawing on experimental archaeology}

Erica Weston, Katherine Szabó and Nicola Stern

\section{FIGURE CAPTIONS}

\section{Figure 1:}

Map of Australia showing the location of the Willandra Lakes, the position of Lake Mungo within the overflow system and the study area in the central Mungo lunette.

\section{Figure 2:}

(a) Alathyria condola, (b) Velesunio ambiguus and (c) A. jacksoni

\section{Figure 3:}

Surface and edge attrition and polish associated with 'sandblasting'. Note the smoothing of all surfaces and delamination of nacre sheets. Scale is in millimetres.

\section{Figure 4:}

An example of an experimentally-notched hyriid specimen used for this study.

\section{Figure 5:}

Experimental hyriid use showing materials and the ways in which valves were held: (a) possum skin scraping; (b) bulrush scraping; (c) River Red Gum scraping, and; (d) sweet potato peeling.

\section{Figure 6:}

Examples of use-wear signatures noted on experimental specimens: (a) a valve used for possum skin scraping showing polish, rounding and the zone of accumulation of detritus back from the working edge; (b) working edge of a valve used for scraping bulrush showing edge-rounding, polish and the accumulation of plant material in a band back from the working edge.

\section{Figure 7:}

Examples of use-wear signatures noted on experimental specimens: (a) edge of a valve used for scraping Red River Gum bark showing edge-rounding and faceting, and micro-chipping; (b) edge of a valve used for scraping Red River Gum showing edge-rounding, microchipping and the differential wear and fracture of different layers of nacre.

\section{Figure 8:}


Examples of use-wear signatures noted on experimental specimens used for peeling sweet potatoes: (a) edge-rounding, polish and exfoliation of nacre sheets at the margin and adhering residues; (b) micro-chipping and exfoliation at the valve margin.

\section{Figure 9:}

Hyriid shell tool \#1110; valve exterior (I) and interior ( $r$ ) views. Lower image: close-up of concentrated zone of edge-rounding and polish indicated by white lines.

\section{Figure 10:}

Hyriid shell tool \#1108; valve exterior (upper) and interior (lower) views. Under magnification (a) shows differential wear between shell layers at the margin indicated by white lines, as well as edge-smoothing and rounding; (b) shows edge-rounding visible from the outer surface as well as surface abrasion on the most elevated portions of the valve exterior from the action of wind-blown sand.

\section{Figure 11:}

Hyriid shell tool \#1104; valve exterior (upper) and interior (lower) views. Under magnification (a) shows a deeply-incised notch indicated with a white ' $v$ ' with smoothed edges and polish on the surrounding surfaces; (b) shows the removal of exterior shell layers in a broad band back from the working edge and especially concentrated in the zones to either side of notches. The inner limit of these removed layers is indicated by the grey line.

\section{Figure 12:}

Possible hyriid shell tool \#1086; valve exterior (upper) and interior (lower) views. Under magnification (a) shows the attrition of nacre layers at the valve margin with the width of this band of attrition indicated by the grey line; (b) shows the uniform wear of different lamellae at the margin on the valve exterior.

\section{Figure 13:}

Unworked fragments from the Mungo lunette showing various taphonomic alterations: (a) \#1107 showing sharp, rough edges and (b) taphonomic micro-chipping along the ventral margin; (c) \#875 showing rounding, polish and delamination from the action of wind-borne sand; (d) \#1064 showing an unworked edge with sharp-edged, lamellar recent breakage. 

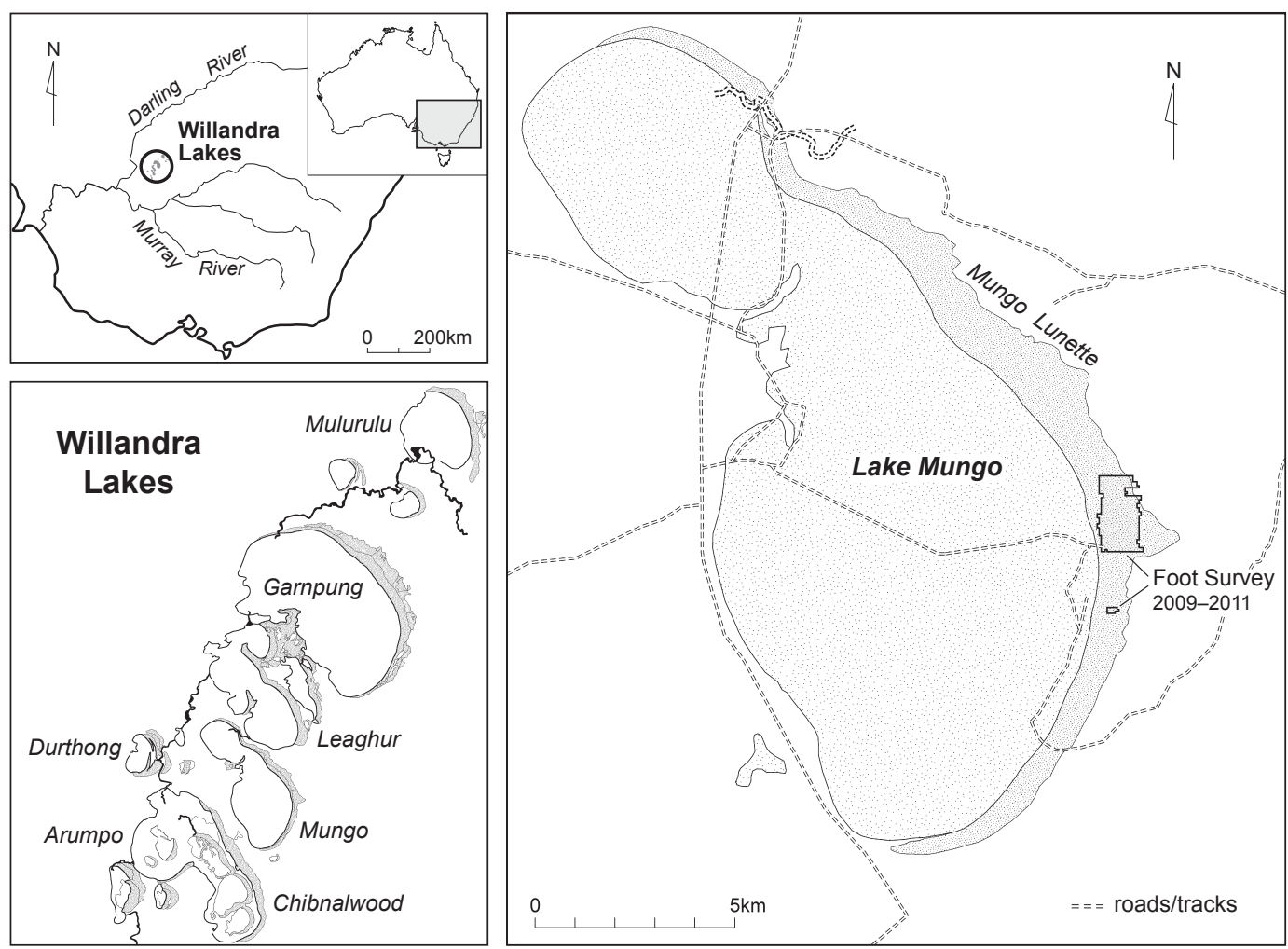

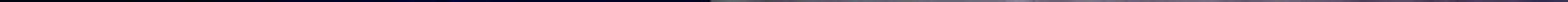


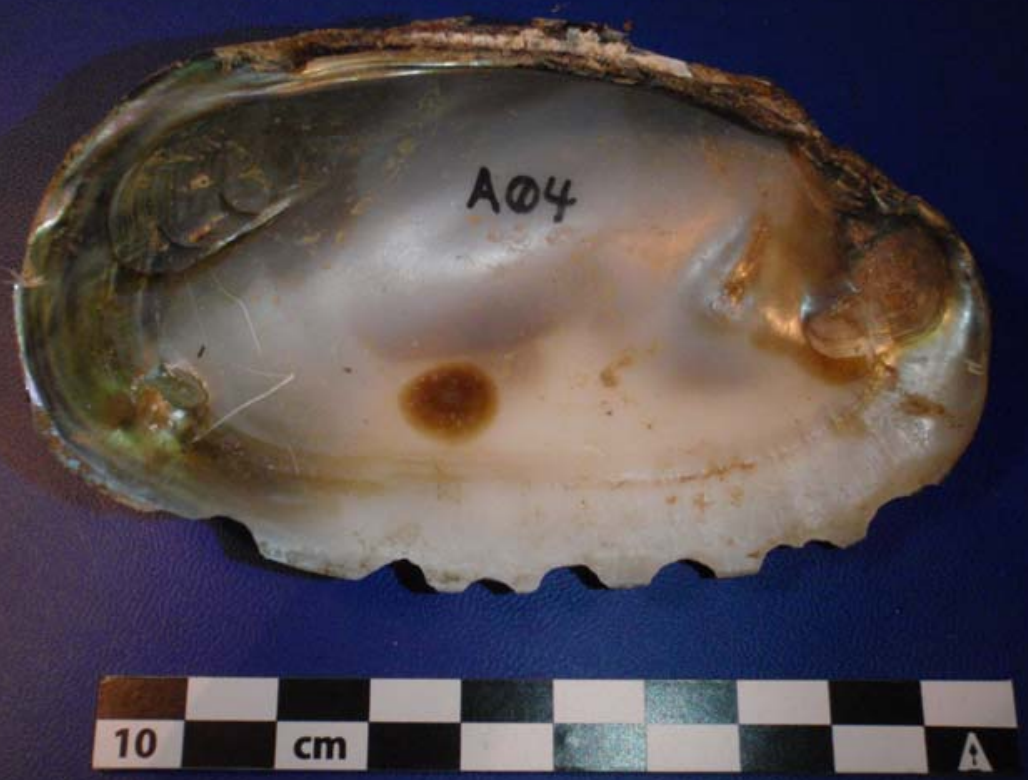




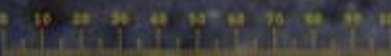

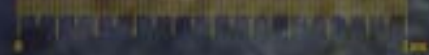

\section{$x^{2}+2-6$}

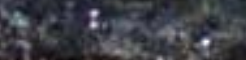

W.

5

$3 x$

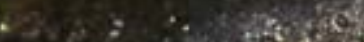

What

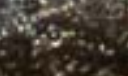

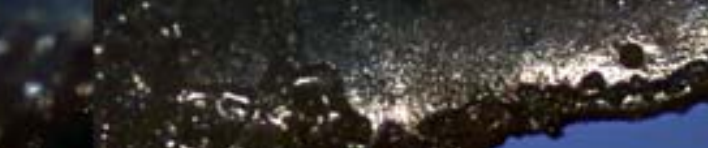

8. 20 

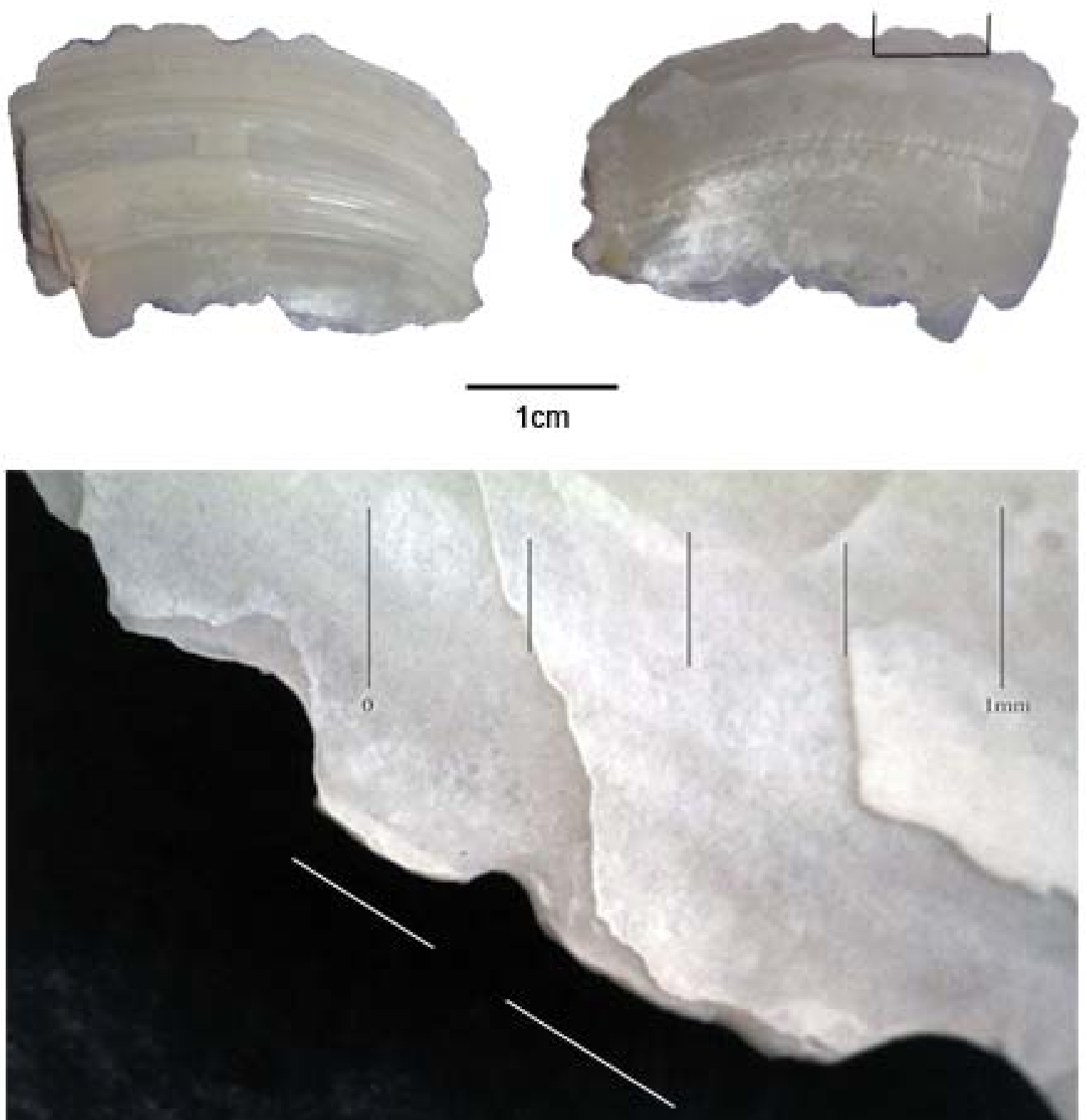

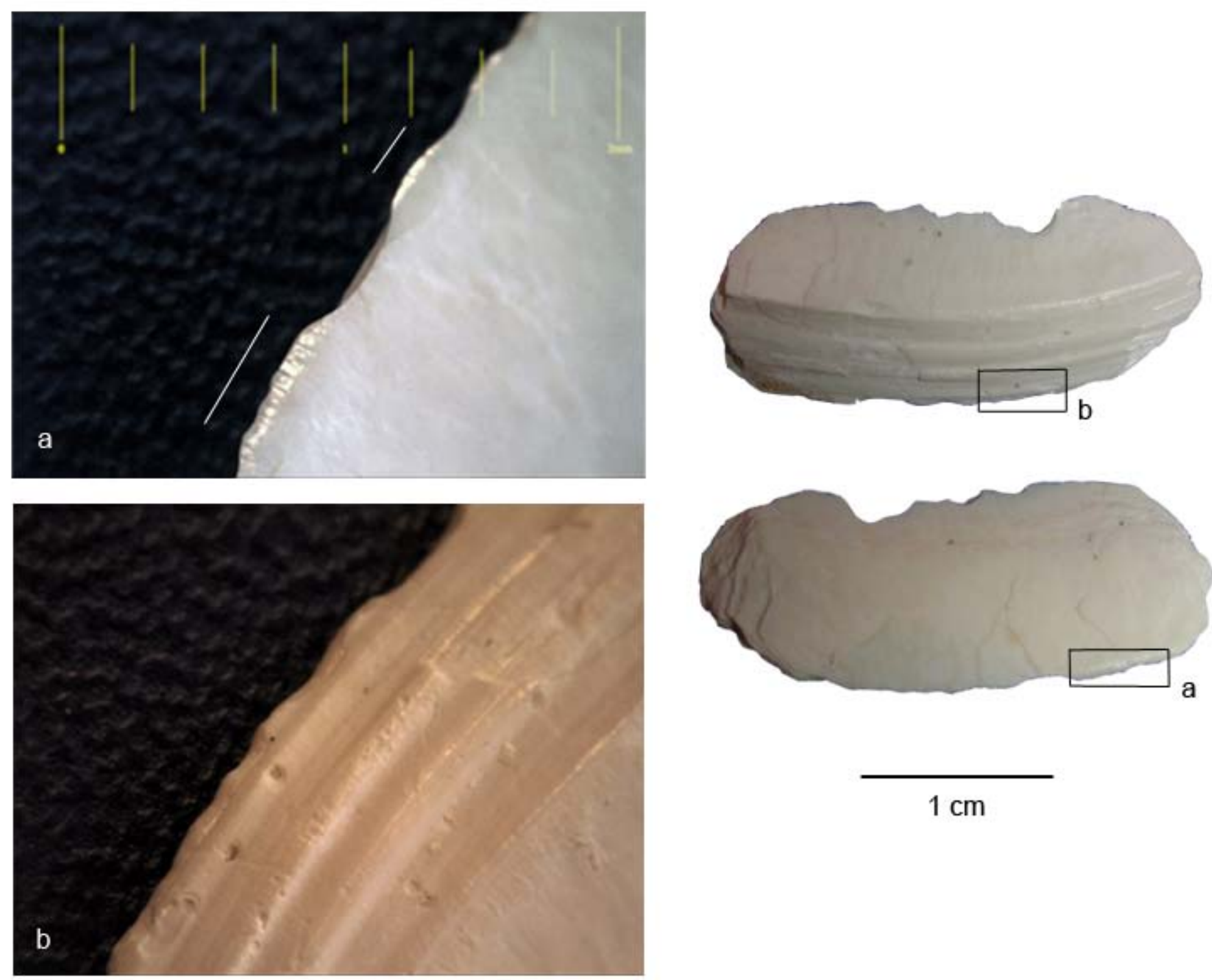

$1 \mathrm{~cm}$ 


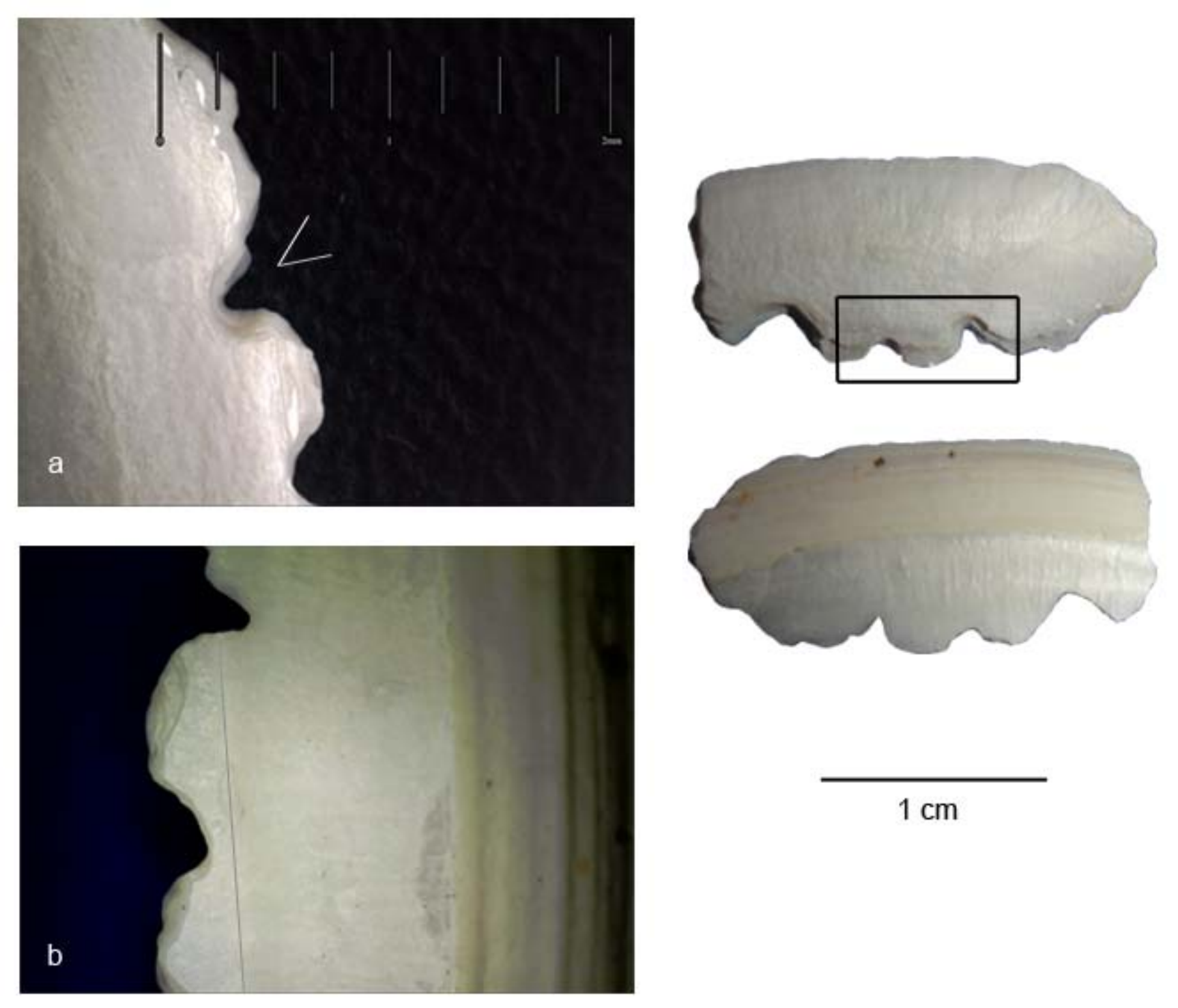



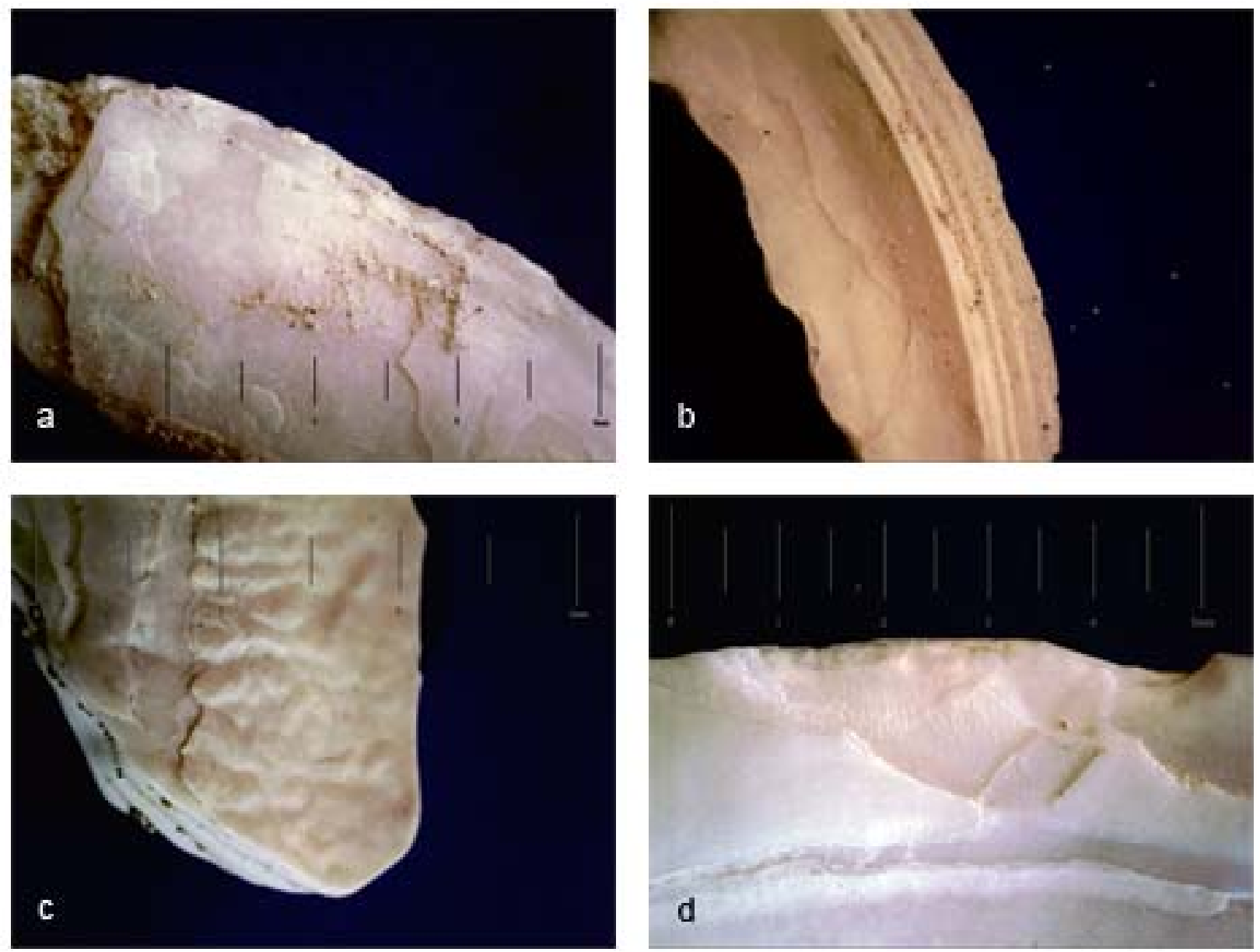